\title{
Determination of minimum quantity of pollen and nutritive value of different carbohydrates for Scaptotrigona depilis Moure (Hymenoptera, Apidae)
}

\author{
PG Fernandes-da-Silva ${ }^{1}$, G Muccillo ${ }^{2}$, FS Zucoloto ${ }^{1^{*}}$ \\ ${ }^{1}$ Biology Department, Faculty of Philosophy, Sciences and Arts of Ribeirão Preto, \\ University of São Paulo, Av dos Bandeirantes 3900 CEP 14040-901, Ribeirão Preto SP; \\ 2 Department of Geology, Physics and Mathematics, Faculty of Philososphy, \\ Sciences and Arts of Ribeirao Preto, University of São Paulo, SP, Brazil
}

(Received 28 February 1992; accepted 12 November 1992)

\begin{abstract}
Summary - Two experiments were performed to determine some aspects of nutrition in Scaptotrigona depilis. This minimum quantity of pollen necessary for suitable development of hypopharyngeal gland and oocytes was determined to be $=8.0 \mathrm{mg} / \mathrm{bee} / \mathrm{d}$. With respect to carbohydrates, no differences in longevity were found between groups fed sucrose $(w / v)$ at 10,30 or $50 \%$. With different carbohydrates (glucose, fructose, sucrose and maltose) no differences were detected between groups fed all carbohydrates at $1 \%$; groups fed sucrose, maltose and glucose were similar to groups fed sucrose; the sucrose group was similar to the maltose and glucose groups; the maltose and glucose groups were similar. For all carbohydrates, $10 \%$ concentration showed superior results to $1 \%$ concentration.
\end{abstract}

Scaptotrigona depilis / pollen / carbohydrate / nutrition / Meliponinae

\section{INTRODUCTION}

In the Hymenoptera, only bees collect both nectar and pollen from flowers (Michener, 1974; Waddington, 1987). Other alternative food sources for bees are honeydew (Vogel, 1931; Taber et al, 1975; Kevan et al, 1983) and, in some cases, food is obtained by a certain degree of cannibalism (Webster et al, 1987).

In the winter or when few flowers are blooming, bee colonies experience diffi- culty in obtained food, with a consequent limitation of colony activities. To avoid problems of this type, beekeepers usually supply pollen substitutes (Schmidt et al, 1989) and sucrose solutions (Taber, 1989) during periods of food scarcity.

Some investigators have made attempts to obtain a good substitute diet for Meliponines. Camargo (1976) used pollen of Typha dominguensis as the main substitute for the pollen normally used by Melipona and Scaptotrigona. In another

* Correspondence and reprints 
study (Zucoloto, 1977), 8 substitutes for the pollen utilized by Scaptotrigona postica were tested and a mixture of $18 \%$ brewer's yeast and $82 \%$ commercial sucrose was found to be a good alternative for pollen. In another study on S postica, Testa et al (1981) tested the nutrient value of different mixtures of the pollen used by this species with the pollen used by Apis mellifera and concluded that a $75 \%: 25 \%$ mixture of the two, respectively, was a satisfactory substitute for the pollen used by $S$ postica. Fernandes-da-Silva and $\mathrm{Zu}$ coloto (1990) developed a substitute diet for $S$ depilis based on brewer's yeast fermented with the pollen utilized by the species.

Research in this area is important to determine the pollen and/or carbohydrate deficiencies in hives and thus supply a substitute for the food used by the bees. There is also an interest in keeping the colonies in good condition throughout the year to permit biological studies in the laboratory and in the field.

The determination of the minimum amount of food and of adequate nutrient concentrations is also useful for development of artificial diets for the species under study, thus permitting more detailed studies in the laboratory.

The objectives of the present study were: 1) to determine the minimum amount of pollen needed for normal development of hypopharyngeal glands (HPG) and oocytes in $S$ depilis workers; and 2) to determine the best concentrations of glucose, fructose, sucrose and maltose for this species.

\section{MATERIALS AND METHODS}

Bees were collected as follows: brood combs were removed at the time of emergence from the same colony throughout the experiment and placed in an incubator similar to that described by Sakagami and Zucchi (1963) with a controlled temperature of $28-30^{\circ} \mathrm{C}$ and $\approx 70 \%$ relative humidity. Brood combs were left in the incubator inside a wood box (18.3 x $18.3 \times 4.3$ $\mathrm{cm})$ covered with a glass lid. As the bees emerged (0-24 h), they were placed in the corresponding experimental acrylic boxes $(11 \times 11$ $\times 3 \mathrm{~cm}$ ) with acrylic lids, containing the appropriate food for each group. Water or a carbohydrate solution was supplied through a hole in one side of the experimental box, depending on the group. The experimental boxes were placed in the incubator described above and it was covered with black cardboard to keep the light out. Diet composition and experimental groups will be described later. Overall, the experimental methodology is similar to that used in other nutritional studies (Groot, 1952, 1953; CruzLandim and Akahira, 1966; Barker and Lehner, 1973, 1974a, b; Zucoloto, 1975, 1976, 1977, 1979; Peng and Jay, 1976; Testa et al, 1981; Crailsheim and Stolberg, 1989; Schmidt et al, 1989).

All groups contained 12 individuals in each of 2 replicate cages. The data were pooled for statistical analysis by the Mann-Whitney or Kruskal-Wallis tests, with the level of significance set at 5\% (Hollander and Wolfe, 1973; Siegel, 1975).

\section{Determination of minimum quantity of pollen}

The bees were allowed to feed for $8 d$ after which they were fixed in Dietrich solution for $48 \mathrm{~h}$ and transferred to $70 \%$ alcohol until dissection. The 8-d time interval proved to be adequate on the basis of HPG and oocyte development (Dias and Simões, 1972; Testa et al, 1981). The nutritional value of the diet was analyzed on the basis of the development of the hypopharyngeal gland (HPG) and oocytes (CruzLandim and Akahira, 1966; Zucoloto, 1977, Testa et al, 1981; Fernandes-da-Silva and Zucoloto, 1990).

The HPG were analysed in terms of cellular size measured by cellular diameter of 10 cells randomly selected per bee. Oocyte lengths and widths of the largest oocyte in each ovary were measured and means obtained (Testa et al, 
1981; Fernandes-da-Silva and Zucoloto, 1990). Cells and oocytes were stained with a $4 \%$ acetic carmine, by immersion for $3 \mathrm{~min}$. All bees alive on the 8th $d$ were dissected.

\section{Nutritional value of different concentrations of sucrose and other carbohydrates}

Solutions containing different concentrations of commercial sucrose (w/v), ie, 1, 10, 30 and $50 \%$ were fed to caged bees and the nutritional value determined on the basis of bee longevity according to Zucoloto (1979). Longevity was also used to compare sucrose to fructose (Merck), glucose (Merck), and maltose (Gibco), all offered at concentrations of 1 and $10 \%(w / v)$. The test sugar solution was the only food offered to bees and control groups fed tap water only.

Bee longevity data (days $\pm S D$ ) in relation to sucrose solution show that the groups fed water lived $1.17 \pm 0.38^{\mathrm{a}}$, and $1 \%$ sucrose solution lived $2.50 \pm 2.74^{\mathrm{a}}$. For the groups fed 10,30 and $50 \%$ sucrose solutions, the results were $18.46 \pm 8.16^{\mathrm{b}} ; 19.29 \pm 7.69^{\mathrm{b}}$ and $17.96 \pm 8.69^{\mathrm{b}}$, respectively. Means followed by the same letter did not differ statistically $(P>0.05$; KruskalWallis test).

For comparison of the various carbohydrates, concentrations of 1 and $10 \%$ were used based on the results of the previous experiment in which $10 \%$ sucrose concentration appeared to provide good nutritional value to the bees

\section{RESULTS}

In $S$ depilis the importance of pollen on HPG and oocyte development was not confirmed. To clarify this point, one group of bees received pollen and sucrose $50 \%$ (weight/volume - therafter $w / v$ ) ad libitum, and another group received only sucrose $50 \%$ ad libitum. The results obtained for HPG were: $49.91 \pm 3.46^{\mathrm{a}}$ and $26.92 \pm$ $1.31^{\mathrm{b}}$ respectively; for oocytes, the results obtained were: $198.00 \pm 79.71^{\mathrm{a}}$ and 98.96 $\pm 14.61^{\mathrm{b}}$, respectively. Means followed by different letters differ statistically ( $P \leq 0.05$; Mann-Whitney test). These results show the importance of the pollen to HPG and oocyte development.

Diets were supplied only once to each group with $0.25,0.50$ and $0.75 \mathrm{~g}$ of pollen. The pollen was collected once from the closed pots inside the hive. A $50 \%$ commercial sugar solution (w/v) was offered separately to all groups as a carbohydrate source; the sugar solution was changed daily.

The results obtained are summarized in table I. Statistical analysis of the data showed that 0.25 and $0.50 \mathrm{~g}$ of pollen was insufficient, whereas $0.75 \mathrm{~g}$ was sufficient for adequate HPG and oocyte develop-

Table I. Mean size of hypopharyngeal gland cell and mean oocyte size in bees fed different quantities of pollen.

\begin{tabular}{clcc} 
No of bees dissected & \multicolumn{1}{c}{ Diets } & $\begin{array}{c}\text { Hypopharyngeal gland } \\
(\mu m \pm S D)\end{array}$ & $\begin{array}{c}\text { Oocytes } \\
(\mu m \pm S D)\end{array}$ \\
\hline 12 & Pollen + sucrose (control) & $54.67 \pm 2.13$ & $495.00 \pm 177.24$ \\
12 & $0.25 \mathrm{~g}$ pollen + sucrose 50\% & $34.96 \pm 1.65^{\star}$ & $123.64 \pm 25.77^{\star}$ \\
12 & $0.50 \mathrm{~g}$ pollen + sucrose 50\% & $34.06 \pm 2.64^{\star}$ & $106.04 \pm 17.20^{\star}$ \\
18 & 0.75 g pollen + sucrose 50\% & $48.08 \pm 3.37^{\star \star}$ & $209.72 \pm 77.96^{\star \star}$
\end{tabular}

\footnotetext{
* Statistically different from control; ** Not statistically different from the control.
} 
ment. These present data suggest that the minimum amount of pollen for adult worker bees of this species is $\approx 0.80 \mathrm{mg} / \mathrm{bee} /$ day, together with $50 \%$ sucrose supplied ad libitum.

The results, which are summarized in table II, show that with respect to the groups fed the $1 \%$ concentration, the bees fed water had a statistically shorter longevity than the group fed fructose and a statistically identical longevity to the groups fed sucrose, maltose and glucose. The groups fed sucrose, fructose, maltose and glucose presented statistically identical Iongevity amongst themselves.

With respect to the groups fed $10 \%$ concentration, the bees fed water had statistically shorter longevity than the bees in all other groups. The longevity of bees fed sucrose was statistically indentical to that of bees fed fructose, maltose and glucose. The longevity of the bees fed fructose was statistically longer than that of the groups fed maltose and glucose, and the longevity of the groups fed maltose and glucose was statistically identical.

Table II. Mean longevity of bees fed carbohydrates in $1 \%$ and $10 \%$ concentrations.

$\begin{array}{ccc}\text { Group } & \begin{array}{c}\text { Nutrient } \\ (w / v)\end{array} & \begin{array}{l}\text { Longevity } \\ (d \pm S D)\end{array}\end{array}$

\begin{tabular}{rllc}
\hline & & & \\
1 & Water & & $1.46 \pm 0.51^{\mathrm{a}}$ \\
2 & Sucrose & $1 \%$ & $2.58 \pm 2.55^{\mathrm{ab}}$ \\
3 & Fructose & $1 \%$ & $7.21 \pm 4.75^{\mathrm{b}}$ \\
4 & Maltose & $1 \%$ & $4.75 \pm 3.65^{\mathrm{ab}}$ \\
5 & Glucose & $1 \%$ & $3.38 \pm 3.09 \mathrm{ab}$ \\
6 & Water & & $1.50 \pm 0.59 \mathrm{c}$ \\
7 & Sucrose & $10 \%$ & $15.83 \pm 7.60^{\mathrm{de}}$ \\
8 & Fructose & $10 \%$ & $22.58 \pm 5.01^{\mathrm{e}}$ \\
9 & Maltose & $10 \%$ & $15.54 \pm 5.90^{\mathrm{df}}$ \\
10 & Glucose & $10 \%$ & $15.67 \pm 6.89 \mathrm{df}$ \\
& & & \\
\hline
\end{tabular}

Means followed by the same letter did not differ statistically $(P>0.05)$; Kruskal-Wallis test.

\section{DISCUSSION}

It is important to establish a parameter for the minimum amount of food, since this may affect individual development and longevity (Groot, 1952). The effect of dietary protein content for adults of $S$ postica has been studied in depth in the glands of the salivary system (hypopharyngeal, mandibular and thoracic salivary glands) both at the histological and the morphological levels by Cruz-Landim and Akahira (1966). The results obtained showed that HPG were influenced by the presence of pollen in the diet. Oocytes are also affected by dietary protein as shown in our study and previously by Sakagami et al (1963).

Sucrose is commonly found in plants and animal tissues and is normally utilized by most insects (Dadd, 1985); glucose, maltose and fructose were also found in the nectar of the bees (Waddington, 1987). The similar results obtained with sucrose at different concentrations, suggest that bees ingest the carbohydrate at different rates. That is, the ingestion can be proportionally inverse to the carbohydrate concentration, as suggested by Zucoloto (1976). According to Crailsheim (1988), although bees of the genus Apis prefer sugars at high concentrations, 3 mechanisms may be proposed for bee survival on diets containing low sugar concentrations: 1) the presence of peritrophic membranes which prevent rapid transport, thus facilitating absorption; 2) increased sugar concentration due to the rapid absorption of the water in which they are dissolved, or transport to the haemolymph together with water; and 3) the absorbed sugars are efficiently distributed to the organs by the rapid haemolymph circulation, especially during periods of intense muscular activity (such as flight).

Concerning the experiment of various carbohydrates, the results first indicate that the longevity of the bees increases with 
carbohydrate concentration (table II). Hainsworth et al (1990) reported that virtually all of the sucrose, glucose and fructose ingested by blowflies and by other animals feeding on nectar is assimilated regardless of concentration. Thus, we may assume that, within certain limits, only the increase in sugar concentration is responsible for the difference in longevity observed in the various groups fed 1 and $10 \%$ concentrations, since absorption is not impaired.

In a study on S postica, Zucoloto (1976) reported that the nutritional value of sucrose is better than that of fructose, which in turn is better than that of glucose. The data obtained for the longevity of $S$ depilis feeding - on various carbohydrates showed no difference between fructose, sucrose or glucose at $1 \%$ concentration, and fructose was superior to glucose and similar to sucrose at $10 \%$. We conclude that the observed longevity among bees fed only carbohydrates was essentially due to carbohydrate concentration and or utilization.

Résumé - Détermination des besoins minimaux en pollen et de la valeur nutritive de différents glucides pour Scaptotrigona depilis Moure (Hymenoptera, Apidae). Déterminer les besoins minimaux et les concentrations adéquates de nourriture est utile pour maintenir les colonies en bonnes conditions tout au long de l'année et mettre au point des régimes artificiels pour l'espèce étudiée. Le travail présenté avait pour but de déterminer: 1) la quantité minimale de pollen nécessaire au développement normal des glandes hypopharyngiennes (HPG) et des ovocytes chez les ouvrières de Scaptotrigona depilis et 2) les meilleures concentrations des solutions de glucose, fructose, saccharose et maltose pour la même espèce. Dans les 2 cas on a utilisé des ouvrières naissantes (0-24 h). Elles ont été encagées dans des boîtes en acrylique placées dans une étuve (température de $29 \pm 1{ }^{\circ} \mathrm{C}$ et une humidité relative de $70 \%$ ). Une quantité connue de pollen et un sirop du commerce à $50 \%$ (poids/ vol) ont été fournis à chaque groupe d'abeilles. Celles-ci se sont nourries pendant $8 \mathrm{j}$, puis ont été fixées et disséquées. L'analyse statistique des données (tableau 1) suggère que les besoins minimaux en pollen pour le développement des HPG et des ovocytes sont d'environ $8 \mathrm{mg} / \mathrm{j}$ par ouvrière adulte en plus d'un sirop de saccharose à $50 \%$ donné ad libitum. La valeur nutritive des glucides a été établie d'après la longévité des abeilles. La solution sucrée était la seule nourriture fournie aux divers groupes. Les résultats montrent que les concentrations en saccharose (poids/ volume) de 10,30 et $50 \%$ sont équivalentes, alors que la concentration de $1 \%$ donne le même résultat, statistiquement inférieur, que le groupe témoin qui n'a reçu que de l'eau. Pour comparer les divers glucides entre eux, on a choisi, d'après les résultats de l'expérience précédente, des concentrations de 1 et $10 \%$. Le tableau II montre que les abeilles nourries avec du fructose, du saccharose, du maltose ou du glucose à $1 \%$ ont la même longévité; à la concentration de $10 \%$, le fructose est supérieur au glucose et au maltose et égal au saccharose. Pour tous les glucides testés, les solutions à $10 \%$ sont plus performantes que les solutions à $1 \%$.

\section{Scaptotrigona depilis / pollen / glucide / nutrition / Meliponinae}

\section{Zusammenfassung - Bestimmung der Mindestmengen an Pollen und der Năhr- wert von verschiedenen Carbohydraten in unterschiedlicher Konzentration für Scaptotrigona depilis Moure (Hym,} Apidae). Während des Winters und zur Zeit geringen Blütenangebotes entstehen für die Bienenvölker Schwierigkeiten beim 
Nahrungserwerb und damit Einschränkungen bei den Volksaktivitäten. Es besteht aber ein Interesse, die Völker während des ganzen Jahres für biologische Studienim Laboratorium oder im freien in guter Verfassung zu halten. Ebenso ist die Bestimmung des geringsten Nahrungsbedarfs und der ausreichenden Konzentration der Nährstoffe zur Entwicklung künstlicher Futtermittel für die untersuchte Bienenart von Bedeutung.

Die Ziele der vorliegend Studie waren: 1) Bestimmung der geringsten Pollenmenge, die für eine normale Entwicklung der Futtersaftdrüsen (HPG) und der Oozyten bei Arbeiterinnen von Scaptotrigona depilis notwendig ist; 2) Bestimmung der besten Konzentration von Glukose, Fruktose, Saccharose und Maltose für diese Art. Für beide Experimente wurde frischgeschlüpfte Bienen (0-24 h) benutzt. Während der Experimente wurden die Bienen in Käfigen aus Acryl in einem Thermostaten bei einer Temperatur von $29 \pm 1{ }^{\circ} \mathrm{C}$ und $70 \%$ relativer Feuchte gehalten.

Um den niedrigsten Pollenbedarf zu bestimmen, wurde jeder Bienengruppe eine bekannte Pollemenge und außerdem eine $50 \%$ Zuckerlösung als Kohlenhydratquelle geboten. Die Bienen wurden für 8 Tage auf dieser Nahrung gehalten, dann wurden sie konserviert und präpariert. Untersucht wurden die Futtersaftdrüsen und die Oozyten. Die statistische Analyse der Daten (Tabelle I) weist darauf hin, daß der niedrigste Pollenbedarf der erwachsenen Arbeiter dieser Art etwa $8 \mu \mathrm{g} /$ Biene/Tag beträgt, zusammen mit dem Angebot einer $50 \%$ igen Zuckerlösung ad libitum.

Bei den Kohlenhydrat-Versuchen wurde der Nährwert auf Grund der Langlebigkeit der Bienen bestimmt. Die Kohlenhydratlösung war die einzige Nahrung, die dieser Gruppe geboten wurde. Die Ergebnisse zeigen, daß Saccharosekonzentrationen von 10,30 und $50 \%$ einander gleichwertig zeigten, während die mit Lösungen von $1 \%$ und die mit Wasser allein gefütterte Kontrollgruppen einander ähnlich und den übrigen statistisch unterlegen waren ( $\mathrm{Ta}$ belle II).

Zum Vergleich der verschiedenen Kohlenhydrate (Saccharose, Maltose, Fruktose und Glukose) wurden auf grund der Ergebnisse des eben beschriebenen Experiments Konzentrationen von 1 und 10\% eingesetzt. Die in Tabelle II zusammengefaßten Ergebnisse zeigen eine ähnliche, leicht verlängerte Lebensdauer für alle Zuckerarten, wobei jedoch Fruktose am besten abschnitt. Bei Fütterung mit $10 \%$-igen Lösungen war die Lebensdauer allgemein um ein Mehrfaches höher, wobei wiederum die Fruktose am besten abschnitt.

Scaptotrigona depilis / Pollen / Kohlenhydrate I Meliponinen (Stachellose Bienen) / Ernährung

\section{REFERENCES}

Barker RJ, Lehner Y (1973) Acceptance and sustentative values of honey, the sugars of honey and sucrose fed to caged honey bee workers. Am Bee J 113 (10), 370-371

Barker RJ, Lehner Y (1974a) Food choice changes in aging honey bees. Ann Entomol Soc Am 67 (4), 717-718

Barker RJ, Lehner $Y$ (1974b) Acceptance and sustenance value of naturally occurring sugars fed to newly emerged adult workers of honey bees (Apis mellifera L). J Exp Zool 187 (2), 277-286

Camargo CA de (1976) Dieta semi-artificial para abelhas da subfamilia Meliponinae (Hymenoptera, Apidae). Ciênc Cult 28, 430-431

Crailsheim K (1988) Intestinal transport of sugars in the honeybee (Apis mellifera L). $J$ Insect Physio/ 34 (9), 839-845

Crailsheim K, Stolberg $E$ (1989) Influence of diet, age and colony condition upon intestinal 
proteolytic activity and size of the hypopharingeal glands in the honeybee (Apis mellifera L). J Insect Physiol 35 (8), 595-602

Cruz-Landim C, Akahira $Y$ (1966) Influência da alimentação no desenvolvimento de algumas glândulas de Trigona (Scaptotrigona) postica Latreille (Hymenoptera - Apoidea). Papéis Avulsos Dep Zool S Paulo 19 (6), 63-78

Dadd RH (1985) Nutrition: organisms. In: Comprehensive Insect Physiology, Biochemistry and Pharmacology (Kerkut GA, Gilbert I, eds) Pergamon Press

Dias LBL, Simões D (1972) Relação entre estrutura etária (normal e anormal) de colônias de Scaptotrigona postica Latreille e desenvolvimento glandular (Hymenoptera: Apidea). In: Homenagem à WE Kerr (Cruz-Landim C, Hebling NI, Lello E, Takahashi CS, eds) Facultade de Filosofia Ciencias e Letras, Rio Claro

Fernandes-da-Silva PG, Zucoloto FS (1990) A semi-artificial diet for Scaptotrigona depilis Moure (Hymenoptera, Apidea). J Apic Res 29 (4), 233-235

Groot AP de (1952) Effect of a protein diet on the longevity of caged bees. Physiol Comp Oecol 6, 272-274

Groot AP de (1953) Protein and amino acid requirements of the honeybees (Apis mellifera L). Physiol Comp Oeco/ 3 (2/3), 197-285

Hainsworth FR, Fisher G, Precup E (1990) Rates of energy processing by blowflies: the uses of a joule vary with a food quality and quantity. J Exp Biol 150, 257-268

Hollander M, Wolfe DA (1973) Nonparametric Statistical Methods. John Wiley and Sons, NY

Kevan PG, Helens SSt, Baker L (1983) Honeybees feeding from honeydew exudate of diseased Gambel's oak in Colorado. J Apic Res 22(1); 53-56

Michener CD (1974) The Social Behavior of the Bees. Belknap Press Harvard Univ Press, Cambridge, MA

Peng YS, Jay SC (1976) The effect of diet on queen rearing by caged honeybees. Can $J$ Zool 54 (7), 1156-1160

Sakagami SF, Zucchi R (1963) Oviposition process in a stingless bee, Trigona (Scaptotrigo- na) postica Latreille (Hymenoptera). Stud Entomol 6 (1/4), 497-510

Sakagami SF, Beig D, Zucchi R, Akahira Y (1963) Occurrence of ovary-developed workers in queenright colonies of stingless bees. Rev Bras Biol 23 (2), 115-129

Schmidt JO, Buchmann SL, Glaiim M (1989) The nutritional value of Typha latifolia pollen for bees. J Apic Res 28 (3), 155-165

Siegel S (1975) Estatística näo Paramétrica. McGraw-Hill

Taber S (1989) Feeding bees. Am Bee $J 129$ (3), 167-168

Taber S, Barker RJ, Lehner Y (1975) Sugars collected by honey bees from honeydew of the scale Toumeyella mirabilis (Cockerell), on mesquite. Environ Entomol 4 (3), 439-440

Testa PR, Silva AN, Zucoloto FS (1981) Nutritional value of different pollen mixtures for Nannotrigona (Scaptotrigona) postica. J Apic Res 20 (2), 94-96

Vogel B (1931) Über die Beziehungen zwischen Süssgeschmack und Nährwert von Zuckern und Zuckeralkoholen bei der Honigbiene. $Z$ Vergleich Physiol 14, 273-347

Waddington KD (1987) Nutritional ecology of bees. In: Nutritional Ecology of Insects, Mites, Spiders and Related Invertebrates (Slansky F Jr, Rodriguez JG, eds) John Wiley and Sons, NY

Webster TC, Peng YS, Duffey SS (1987) Conservation of nutrients in larval tissue by cannibalizing honey bees. Physiol Entomol 12, 225-231

Zucoloto FS (1975) Valor nutritivo de pólens usados por diferentes espécies de abelhas para Nannotrigona (Scaptotrigona) postica. Rev Bras Biol 35 (1), 77-82

Zucoloto FS (1976) Valor nutritivo de alguns carboidratos para Nannotrigona (Scaptotrigona) postica (Hymenoptera, Apoidea). Ciênc Cult 28 (2), 193-194

Zucoloto FS (1977) Nutritive value of some pollen substitutes for Nannotrigona (Scaptotrigona) postica. J Apic Res 16 (1), 59-61

Zucoloto FS (1979) Utilization of carbohydrates by Nannotrigona (Scaptotrigona) postica. J Apic Res 18 (1), 36-39 